\title{
STUDENTS WITH SPECIAL EDUCATIONAL NEEDS IN GREEK HIGHER EDUCATION: ICTS AS A VITAL TOOL FOR INCLUSION
}

\author{
Asimina Riga ${ }^{1 i}$, \\ Vasiliki Ioannidi², \\ Nikolaos Papayiannis ${ }^{3}$ \\ ${ }^{1}$ Educational Sciences and Early Childhood Education, \\ University of Patras, Greece \& Hellenic Open University, \\ Greece \\ 2Faculty of Humanities, \\ Postgraduate Course "Education Sciences: Special Education \\ for People with Oral and Written Language Difficulties", \\ Hellenic Open University, \\ Greece \\ ${ }^{3} \mathrm{MA}$ in American Literature, \\ Aristotle University of Thessaloniki, \\ Greece
}

\begin{abstract}
:
The present paper intends to report and analyze ongoing practices and policies with respect to the inclusion of Students with Special Educational Needs (SEN) and/or disabilities into Higher Education in Greece. To achieve this goal, the researchers systematically searched the current literature sources to find out the extent to and the ways in which European priorities set by article 24 of the Convention on the Rights of Inclusion of Persons with Special Educational Needs and/or Disabilities, have been advocated by Greek educational policy within the Higher Education context. Actually, the literature review demonstrates the existing law framework of the Greek national and local policy whose purpose is to promote the development and implementation of digitally assisted services which ought to take into consideration the needs of students with learning disabilities and comply with the international strides calling for a broader inclusive education. The results of this review showed that Greek universities have endeavored to respond successfully to the Greek legislation's mandates and to fully address anti-discriminatory practice. However, more adjustments and decisive progress steps have to be made in relation to the curriculum and to teachers' professional training to ensure all students' inclusion.
\end{abstract}

i Correspondence: email riga.asimina@ac.eap.gr, rigaasimina@upatras.gr 
Keywords: inclusive education, higher education, information and communication technologies, special educational needs

\section{Introduction}

Nowadays, the constant changes in the global educational scene have brought to surface the realization that Education concerns the main and most sustainable mechanism which directs students to lifelong learning and their ongoing development. In fact, it is the new social, economic and cultural environment itself that makes knowledge and skills such as adaptation, innovation, communication, initiative and entrepreneurship, mandatory in the new conditions of globalization (Ioannidi, 2003).

In particular, Education is a key issue on the 2030 Sustainable Development Agenda, aiming to ensure that quality and lifelong learning without exclusions for people with disabilities and other special population groups is undoubtedly achieved (United Nations, 2015). In this context, creative school envisions effective ways and techniques to develop creative thinking skills and meet the current challenges for inclusion, quality and efficiency (Jeffrey and Woods, 2003). Additionally, Information and Communication Technologies (ICTs) are employed as a medium by which the development of critical and creative thinking skills, communication, collaboration, citizenship and language skills are secured. They also play an instrumental role in all levels of education as admittedly their value and usefulness in both teaching and learning for teachers and students respectively is the subject of scientific research (Meadows, 2004).

At the same time, the number of students with disabilities accessing higher education has increased significantly. This is related to the removal of physical barriers and also to the development of universities with an online methodology (De Cesarei and Baldaro, 2015). The online nature of these universities naturally leads to more accessible and inclusive learning experiences, by removing all mobility barriers and many other inclusion challenges. In this way, university students can have equal access to learning experience, including exposure to knowledge, engagement to learning process and motivation (Iwarsson and Ståhl, 2003). For instance, learners from their own house can access online videos and audio files several times and they can also revise material through educational activities that will instantly give them feedback. However, research shows that a large percentage of schools and universities around the world do not properly promote equal access for all pupils and students, mainly due to the lack of effective teaching methods (Virnes, 2008).

However, inclusion is more typically used to refer to welfare policies targeted at low socio-economic status learners, indigenous, regional and remote, migrants and those for whom the study language is not their first language. Researches and policies are often directed towards adult migrants, refugees and the unemployed rather than learners with disabilities. However, in this study, the term "inclusion" means a fairer educational access and outcomes not for every non-award community-based learners, but for Students with SEN and/ or for Disabled learners. 
In particular, this article presents a brief literature overview in the field of ICT exploitation by the Greek educational system and offers insightful details on the degree of promoting learning and teaching via technology channel in Higher Education without though excluding students with different educational needs from the current educational procedures of the 21st century. The paper reaches the conclusion that significant progress has not been made with respect to establishing inclusive environment because such a context had not been possible to be part of the political agendas which deeply permeate and define the Greek educational system.

\section{Theoretical Framework}

The United Nations Educational, Scientific and Cultural Organization (UNESCO) has played an admittedly influential role in both realizing and considering inclusive education for children with Special Educational Needs an indispensable feature of contemporary schools (UNESCO, 1994). The initiative put forward by UNESCO under the sign "Education for All" (UNESCO, 1990) further highlights the importance of providing a fairly equivalent and objective learning experience to all students regardless of their individual differences, as "globalization is a fundamental factor affecting higher education in this century. More than ever before, the processes of globalization are being integrated into a set of social, technological, economic, cultural and ecological factors, so that we are now beginning to accept that we are facing a completely irreversible world-wide phenomenon".

In general, innovative forms of learning within educational settings regard active learning as a prerequisite. That is the type of learning that is directly related to the preparation, execution, adjustment, control, feedback and retention of learning skills by the students themselves. Its basic characteristics are associated with durability of the educational product over time, with flexibility and global approach as well as the emergence of different perspectives, with adaptability to any new data, with functionality in different space-time contexts and last but not least with usefulness and application (Krokou, 2007). On this basis, learning does not represent a mere information acquisition, but rather a continuous process of resolving internal cognitive conflicts. These conflicts arise but are also resolved within the framework of communication and interaction of the individuals with their natural and social environment (Matsagouras, 2000).

Moreover, the implementation of teaching methods that utilize pedagogically updated educational ICT tools, whose main purpose is to bring educational institutions closer to society and real life as well as to boost students' self-esteem, is also remarkable. Finally, taking into consideration that technology has paved the way for eliminating any obstacles related to the obligatory physical presence of the teacher-student participants in the same space or even time, researchers can then safely draw the conclusion that a widespread use of digital tools such as e-talks, teleconferences, e-mail, whiteboards, chat rooms, HTML-pages, is not only permitted within the contemporary learning settings but highly expected, as well (Pozzi, 2011). 


\section{Higher Inclusive Education in Greece}

As far as Higher Education is concerned, inclusive education practices, lifelong learning dexterities as well as appropriate correspondence to the variable labor market needs are considered as imperative in the most developed and developing countries' legislation. In Greece, for example, the current institutional legacy/policy for the education of individuals with disabilities and special educational needs, is laid down mainly in law $3699 / 2008$. Additionally, the apparent social dimension of national policy, primarily as a result of the provisions of law 4009/2011 and law 4485/2017, is evident in the premise that all students and particularly students of vulnerable social groups receive throughout their studies benefits and facilities through a series of educational and social provisions (https://eacea.ec.europa.eu/national-policies/eurydice). Despite these most beneficial legal requirements, there are still more to be done so as to achieve full equal terms and conditions in Higher Education in Greece, given that the reality of university life for the students with disabilities is characterized by continuous exclusion from the learning procedures mainly due to the actual barriers to learning (Vlachou and Papapanou, 2018). Initially, mandatory requirements in relation to the admission entrance into the Greek Higher Education are determined by a national assessment, through the annual 'PanHellenic' examination. This particular exam procedure, the predetermined number of candidates that will enter universities and the great demand for higher education, urge candidates' parents (Saiti and Prokopiadou, 2008), to seek after-school lessons for their children in private tutoring schools/classes. Surprisingly enough, Psacharopoulos and Tassoulas (2004) estimate that the annual amount of money spent by families for afterschool private tutorial lessons in Greece exceeds the analogous amount paid by the State for public education. As a result, students whose parents have low income are usually associated with poor and consequently low performance, raising as such serious concerns and controversies with respect to the issue of inequality among the candidates (Gouvias et al., 2012; OECD, 2011).

Meanwhile, since students' entrance to a university department depends on correlating their assessment scores with the specific number of candidates that can be accepted by each department as well as with other candidates' preferences, high competition levels are inevitable (Sianou-Kyrgiou and Tsiplakides, 2011).

However, more and more students with SEN or/and disabilities successfully complete their compulsory education, so the need to overcome the existent barriers to inclusion within higher education has emerged. With the exception of students with serious health problems or students with visual and severe mobility disabilities - who can apply for $5 \%$ of the available higher education seats without participating in the PanHellenic examination - the rest of the students with chronic conditions and/or disabilities are obliged to undergo exactly the same procedure as the candidates without any disabilities (Greek Government, 2009). At the same time, the only legitimate flexibility according to the assessment procedure, concerns the option of oral examinations only for those who are legally and medically entitled to. Depending on their scores, candidates 
with SEN or/and disabilities may claim a university seat, among the few offered exclusively to students with a disability as a "special category".

As far as support and services at a Higher Education level are concerned, the existent legislation provides universities with the flexibility to decide on the type of support they would offer. The law, however, does not demonstrate in detail concise policies and, on the contrary, offers general guidelines (Greek Government, 2009). Therefore, University Institutions have to undertake the responsibility of promoting 'inclusion', of ensuring a non-discriminatory environment for all students and rendering access to and participation in learning feasible for everyone regardless of financial and social criteria (Tressou et al., 2007). In this point of view, several Greek University Institutions have undertaken initiatives and provide qualitative services in order to include and support students with SEN and/or disabilities. The most widely- known services such as Disabled Student Support and Accessibility Units and Student Counselling and Psychological Support Centers promise better educational perspectives for those students.

According to the Greek law 4485/2017, the organizational charter of each higher education institution foresees the establishment and operation of student support especially for students with disabilities or students facing difficulties in completing their studies. Within this framework, a considerable number of Greek universities assign, on a rotational basis though, such advisory duties to certain members of their academic staff. To put it more clearly, their main task concerns the provision of supplementary guidance as well as sufficient advice to students with respect to their academic progress and hence their successful graduation (https://eacea.ec.europa.eu/nationalpolicies/eurydice/content/guidance-and-counselling higher-education-27 en).

In addition to it, certain departments have invested heavily in infrastructure and campus adjustments in premises and systems to make it sure that disabled students are not disadvantaged during their studies at University. They, also, offer assistive technology, access services and/or eLearning platforms, aiming at providing greater flexibility to academic staff, so that all students are supported during their courses with online exercises. PowerPoint presentations and information accessibility units are also available for students with disabilities.

While, in recent years, Greek Universities have struggled to incorporate inclusive practices at both institutional and organizational levels, there is still room for improvement as there is a lack of a proactive comprehensive system suitable for promoting wider participation, for developing lifelong skills and establishing supportive mechanisms. Needless to say, of course, that all these features result in fundamental accomplishments. Furthermore, the broad and vague interpretation given to a law, in correlation with the lack of goal orientation, clarifications and measures (European Commission/EACEA/Eurydice, 2014), have brought about the phenomenon in which different Universities, or even different Departments within the same University, follow different rules and practices. Consequently, institutions' commitment to addressing social and educational exclusion and eliminating barriers to learning differs to a 
considerable extent and, inevitably, students' satisfaction over the quality of the services provided may be divergent accordingly (Mitakidou et al., 2008).

\section{ICTs in Greek Higher Education}

Since ICTs have dominated the whole field of education, marking at the same time the great strides of the $21^{\text {st }}$ century-education, the formation of a tertiary informational and educational environment dependent upon an ICT employment, is inevitable. According to Oliver (2003), the use of ICTs as an instructional medium is increasing more and more and might likely continue to modify those strategies employed by both teachers and students during the learning process. First of all, implementing ICTs in Higher Education is urgently calling for a shift from a teacher-based approach to a student-based one (Becker, 1997). ICTs also add extra value to the process of learning and to the organization and management of learning institutions (Byungura and Hansson, 2019). However, it should be clarified that ICTs increase learning efficiency on the condition that they are applied in full compliance with the examination and analysis of their didactic possibilities, namely: visualization of educational material, enhancement of learning interactivity, access to knowledge, prompt control (Nakaznyi et al., 2015).

Effective use of technology within educational settings can inevitably contribute to establishing an inclusive educational environment. Indeed, ICTs motivate students and thus render classes more dynamic and engaging, allowing students to work at their own pace and teachers to move on individually with their students. After that, ICTs eventually offer teachers the opportunity to monitor and evaluate the learning outcome (Ausin et al., 2016). The various representations of target information facilitate learners to faster perceive and better understand the taught context. The Internet indeed boosts co-operative learning and hence encourages dialogue among the participants during the learning process. Being in favour of this style of learning, Higher Education elevates the status of the job market thanks to its more skillful and qualified staff.

In European higher education institutions, while students and teachers seem to be using the newly available ICTs more and more intensively, organizational designs are changing slowly. The lack of a strategy regarding organizational change leads to a weak impact of ICTs on students' overall performance (Ben Youssef, 2008).

Generally speaking, three complementary educational segments are emerging (Jansen, 2019):

- Blended and online mainstream education;

- Blended and online continuous education;

- Non-degree education and online open education and MOOCs.

In this context, e-learning based on ICT facilities is put into existence (Fojtik, 2014). One of the most important features in relation to e-learning concerns students' interaction with the learning materials within the learning environments (Sogol Talebien et al., 2014). In Greece, in particular, distance learning is offered by the Hellenic Open University. In addition, the National and Kapodistrian University of Athens offers a range of distance 
learning courses. On 31 ${ }^{\text {st }}$ May 2012, the Greek parliament signed and ratified the UN Convention on the Rights of Persons with Disabilities (CRPD). Under these provisions, the Greek Constitution is in line with the most progressive constitutions of other foreign countries, adopting in this way the social model of disability. In terms of information disability, libraries and on-line accessibility, new technologies play an essential role in Higher Education, its main goal being to develop and improve suitable services able to fully meet the needs of students with SEN and/or disability.

However, a study investigating the obstacles students with visual disabilities struggle to overcome on a daily basis during their studies in Greek Higher Education Institutes, concluded that there is still significant lack of fundamental infrastructure necessary to facilitate physical mobility and that the existing library facilities fail to satisfactorily respond to the real needs of university students (in fact, the vast majority of them claimed that they had never studied in a library). The research also showed that any support provided, while studying there, was very limited and that most students reported such severe problems that made them re-consider their future engagement under so tough a university environment. Overall, many participants stated that they were not satisfied with the quality of education provided by their department, while the majority of them believed that the undergraduate degree would not give them equal opportunities to find a job (Papadopoulos and Koutsoklenis, 2009).

However, new facilities for distance learning are in progress by each higher education institute with a view to supporting both horizontal educational actions and broader educational needs. This is taking place within the Information Society programme context (call 7) and in compliance with the Ministry of National Education \& Religious Affairs' relevant policies. In addition to the National \& Kapodistrian University of Athens, teleducation centres operate in more than three higher education Institutes; that is, the Athens University of Economics \& Business, the Aristotle University of Thessaloniki and the National Technical University of Athens, University of Patras http://hyperion.math.upatras.gr/tea/, University of Thessaly, University of Ioannina, University of Crete, University of Macedonia, and Higher Technological Education of Piraeus. However, to date, the network of centers is available only to the teaching staff, students, agencies and organizations. Open education modules and certification of studies are not yet available to the general public.

Also, a contemporary approach to e-learning at an academic level represents the so-called "gamification" or "Games Based Learning - GBL". The GBL refers to the use of data and techniques by electronic games aimed at improving the users' learning experience. For example, the role-playing games through which the students experience and grasp a better understanding of the world in a visual mode, though (Moutean, 2011). Also, e-learning can be implemented for academic purposes by higher education institutions addressed as an alternative way of teaching / learning. Nowadays, Greek universities (National and Kapodistrian University of Athens, University of Patras, University of Crete, National Technical University of Athens, Athens University of Economics and business, etc.) offer multiple opportunities for studies (usually 
postgraduate) following this method even in cases of individuals with SEN and/or disability. As Gkirtzh characteristically argues (2009), an actually great advantage ensuing from employing e-learning in higher education institutions is that a wider and more inclusive audience of students, regardless of their different social, cultural and financial backgrounds, emerges. In this way, equal educational standards and perspectives are actually established in the Greek Universities.

Papanikolaou et al. (2003), developed an Adaptive Educational System capable of promoting equal educational opportunities to everyone on the one hand while, on the other, of generating a dynamically personalized educational content by means of providing counseling support to the learners' navigation and study based on goals, on levels of knowledge, on individual progress and learning style. This system, named INSPIRE (Intelligent System for Personalized Instruction in a Remote Environment), offers all learners the opportunity to intervene and express their perspectives about their own characteristics or about their lesson contents and, accordingly, define the attributes of their individual interaction with this System, in an attempt to engage themselves in the learning process.

It is also worth mentioning that, according to Jansen (2019), "Openness is a strong (societal) driver in this, influencing not only changes in these educational provisions but also academics research". Using Open Educational Resources (OERs) entails literature content \& lesson plans while teaching in an innovative and collaborative environment. These resources are also known as Open Educational Practices (OEPs) (Ehlers, (2011). OEPs promote innovative pedagogical models and empower students through lifelong learning. Also, these practices can help to stabilize the learning quality as well as educational outcome in Higher Education (Weller, 2014). In 2012, in the framework of the Operation Programme "Educational and Lifelong Learning" of the Hellenic Ministry of Education, an initiative was launched, with the intention of making the Greek universities become open to public, by offering free of charge their knowledge treasure exclusively through Internet courses. All these online courses exceed 4,000 lectures and are accessible to every interested student via the "National Portal of Open Academic Courses" (http://opencourses.gr/), developed and technically supported by the Academic Internet - GUnet (http://project.opencourses.gr/) (Merakis, 2019).

Similarly, Kouis et al., have developed "Kallipos", the digital repository of open content. Both, E-textbooks and OERs (https://repository.kallipos.gr) were developed within the framework of the project "Kallipos" (https://www.kallipos.gr/en/), which was co-funded by National and European funds. The "Kallipos" Repository contains more than five hundred and twenty academic textbooks as well as more than seven thousand learning objects with high-quality content. All these digital tools are available free of charge and with open licensing for educational use not only by the members of the Academic/Research Community but also by society as a whole. Currently, the content is offered only for Formal Education purposes; yet, it could potentially meet the Nonformal, Informal and Lifelong Learning needs. 
At the same time, it is argued that practices such as MOOCs, online learning communities, social networks, open educational resources, online radio and television or even online newspapers can combine the three basic forms of learning and education; that is, Formal (Typical) education, Non-formal education and Informal education. In fact, open and distance learning, through ICTs use, can connect the three forms of learning with social media depending on the content. In this way, an exchange of views as well as cooperation is promoted. Thus, the possibility of social interaction is rendered more available and collaborative teaching between teachers (educators), students and educational materials is actually achieved. In particular, MOOCs display elements reminiscent of social constructivist and can therefore become powerful tools for developing students' cognitive skills as well as sustaining social action on global health, environmental and human rights issues (Kanellopoulos and Koutsoumpa, 2017).

Given that the special added value of group collaborative teaching scenarios has been recognized by the Greek university community, a number of similar teaching scenarios has been made public through the available lists which are continuously updated by the Educational Technology Lab of EKPA (in detail here for foreign readers...)

(http://etl.eds.uoa.gr/ekpaideftiko-yliko/kelyfos-ekpaideftikonscenarion.html).

Karampiperis and Sampson (2005) propose an authoring system, referred to as ASK-LDT, which utilizes the Learning Design principles so as to provide the means for designing activity-based learning services and systems. The ASK-LDT based on the Learning Design framework principles as well as on the authoring process, consists of the following steps: Definition of Pedagogical Elements (learning or support activity) and Definition of Environment (discussion forum, virtual laboratory etc, on-line chat etc), Statistical Analysis and Content Packaging.

All in all, access to different types of ICTs in education is a reality nowadays especially for the vast majority of the Higher Education students with SEN and/or disability, but, unfortunately, not for everyone. Equal opportunities as far as ICTs are concerned, access through appropriate structure, special Information and Communication Technologies support and specially trained tutors with lots of experience are some of the most necessary pursuits we must work hard to fulfil in both Greece and Europe, as well (Special Education in Europe, 2003).

\section{Conclusion and Future Directions}

In conclusion, this article describes the way in which the rapid development of ICTs in the first decade of the $21^{\text {st }}$ century has really changed the learning environment with the introduction of OERs, MOOCs, Learning Analytics-LA and Educational Data MiningEDM mainly in Higher Education (Gelameris, 2015). Moreover, another noteworthy contribution of this paper concerns its eloquent explanation of how the use of participatory-experiential techniques through ICTs can create authentic interactive learning environments with inclusive perspectives (Armakolas et al., 2019). What has 
been made also clear is that the correlation of ideas, communities and networks through ICTs enhances the development of a collaborative culture of digital educators and students for an exploratory approach to learning within the social and cultural context (Mc Loughlin and Lee, 2008). On a parallel level, it became clear that E-learning itself provides an attractive and promising means of lifelong learning even in cases of disabled people facing chronic health problems because they can gain great benefit from such inclusive digital learning environments (Argyropoulos and Chronopoulou, 2018). Study findings also confirmed that students with disabilities are capable of asserting their needs, challenging institutional discrimination issues and proposing more inclusive alternatives.

However, additional future attention and research is highly recommended on inclusive design and pedagogy, because such approaches as MOOCs and open education programs can continue to be part of the solution to educational and social inequalities in the case that the students are digitally illiterate and the academic staff lack sufficient knowledge on their methodological exploitation (Lambert, 2020; Pachler et al., 2010). Consequently, the scientific educational community should adjust these technological tools to the curriculum so as to make sure that they will not be approached as unintended further barriers. Furthermore, institutional policies and practices in relation to issues of disability and education, should be refined and reconsidered (Vlachou and Papananou, 2018).

Future empirical studies are considered most essential in relation to investigating how instructors and tutors could possibly overcome these obvious limitations e.g. technological, pedagogical, social and organizational barriers, transforming them into the best teaching practices capable of elevating the teaching methods of the Greek Higher Education (Makri, 2018, 756-757). Both policies and practices involved in national and university inclusive education, need to be evidence informed. Such evidence requires observation and feedback from teachers; otherwise, they will not be able to ascertain a clearer picture of what works, in what circumstances and for which students. However, it is worth noting that, according to Koulikourdi (2009) there are no reports of "information seeking behavior" related to people with SEN and/or disabilities in literature, as much for tertiary education as for distance learning, as well.

Finally, all the questions and issues raised before must be addressed as part of the broader study on how higher education institutions nowadays can effectively reform the current non-inclusive and discriminatory educational community into a more inclusive and educationally impartial environment which will equally embrace both typical and special educational children. In this quest, cross-cultural dialogues and understanding can undoubtedly offer new possibilities for inclusive policy-making. Only by identifying the above task not only as an academic enterprise but as an activity leading to an agenda that can be acted on could educational reform efforts towards quality and equality be fulfilled. 


\begin{abstract}
About the Authors
Dr. Riga Asimina is a Special Education Teacher in Secondary and Higher Education. She holds a doctorate in Special Education from the University of Thessaly in Greece. She has taught Special Education and Language Processing at the University of Patras, at Hellenic Open University and at University of Nicosia, Cyprus. Dr Riga is currently adjuct lecturer at the University of Patras and a Personal Exercise Counselor at the Joint Master Degree of University of Patras with University of Nicosia entitled "Special Education". Her research focuses primarily on Language Teaching in students with Special Education Needs and on the use of Information and Communication Technologies (ICT) in Special Needs Education.

Dr. Vasiliki Ioannidi works as Teaching and Research Fellow at the National and Kapodistrian University of Athens, Tutor-Counselor at the Hellenic Open University and Pastoral Institute Training. She studied Philology and she holds a PhD in Pedagogy/ specialization: "Special Education" as Postgraduate Scholar of the Greek State Scholarships' Foundation (School of Philosophy, University of Athens). She has received certification in Adult Education, Adult Educators Training, Open \& Distance Learning and Neuroscience \& Education. She is member of Think Tank "Intelligent Deep Analysis" at the University of Athens and member of ÖGKJP-Sektion Klinische Pädagogik. Research interests: Inclusive Education, Digital Education, Interdisciplinary cooperation in special needs, Teaching \& best practices.

Nikolaos Papayiannis has a BA in English Language and Literature from Aristotle University, Greece and a MA in American Literature and Culture of the same Department. He has twenty-two years of experience in EFL and finally, he has taken active part in scientific article publications.
\end{abstract}

\title{
References
}

1. Argyropoulos, Th., Chronopoulou, I. 2018. "Creating educational material for distance learning nursing education, on the management of patients with diabetes". Nursing [Noshleytikh], 57(2): 147-155. [in Greek].

2. Armakolas, S., Panagiotakopoulos, X., Fragkoulhs, I. 2019. "The educational design of the teleconference with the use and utilization of participatoryexperiential techniques". International Conference in Open $\mathcal{E}$ Distance Learning, 10. [in greek].

3. Ausin, V., Abella, V., Delgado, V., Hortiguela, D. 2016. “Project-Based Learning through ICT. An Experience of Teaching Innovation from the University Classrooms". Formación Universitaria, 9(3). http://dx.doi.org/10.4067/S0718$\underline{50062016000300005}$

4. Becker, w. e. 1997. "Teaching Economics to Undergraduates". Journal of Economic Literature, 35(3): 1347-73. 
5. Ben Youssef, A. 2008. "Uses of Information and Communication Technologies in Europe's High Education Institutions: From Digital Divides to Digital Trajectories". Working Paper ADIS. www.adislab.net (1) (PDF) The impact of ICT's on students' performance in Higher Education: Direct effects, Indirect effects and Organizational change. Available from: https://www.researchgate.net/publication/277032402 The impact of ICT's on s tudents' performance in Higher Education Direct effects Indirect effects and Organizational change [accessed Jun 25 2020].

6. Byungura, J.C., Hansson, H. 2019. "Development and validation of a holistic ITinstitutional alignment model for higher education institutional performance". In Proceedings of Society for Information Technology \& Teacher Education International Conference (pp. 1279-1290), Edited by: K. Graziano. Las Vegas, NV, United States: Association for the Advancement of Computing in Education (AACE). Retrieved June 25, 2020 from https://www.learntechlib.org/primary/p/207809/.

7. De Cesarei, A., Baldaro, B. 2015. "Doing online research involving university students with disabilities: Methodological issues". Comput. Hum. Behav., 53: 374380 .

8. Ehlers, U. 2011. "Extending the territory: From open educational resources to open educational practices". Journal of Open, Flexible and Distance Learning, 15: 1-10.

9. European Commission/EACEA/Eurydice/Eurostat, 2014. Key Data on Early Childhood Education and Care in Europe. 2014 Edition. Eurydice and Eurostat Report. Luxembourg: Publications Office of the European Union.

10. Fojtik, R. 2014. "Mobile Technologies Education". Procedia - Social and Behavioral Sciences, 143, 342-346. https://doi.org/10.1016/j.sbspro.2014.07.417

11. Gelamerhs, D. 2015. "How the new Internet Technologies are shaping the Open and Distance Education in the immediate future". Open Education. The Journal for Open and Distance Education and Educational Technology, 11(1): 51-71. doi: https://doi.org/10.12681/jode.9820 [in Greek].

12. Gkirtzh, M. 2009. “Tracing the route of E-learning in the 'Annals of Education' and applying it to a proposal for the training on Museum Education". In Proceedings $5^{\text {th }}$ International Conference in Open \& Distance Learning. Athens, Greece.

13. Gouvias, D., Katsis, A., Limakopoulou, A. 2012. "School Achievement and Family Background in Greece: A New Exploration of an Omnipresent Relationship". International Studies in Sociology of Education, 22(2): 125-145. doi:10.1080/09620214.2012.700186

14. Greek Government. 2009. Regulation of Issues Related to the University and Technological Higher Education and Other Provisions. N. 3749/156/4-9-2009. Athens.

15. Ioannidi, V. 2003. "ICT as a means of promoting the health of children with special needs in the context of globalization". In Proceedings - $10^{\text {th }}$ International Conference. Hellenic Educational Society. Nafplio. Available from: http://www.pee.gr/wpcontent/uploads/praktika synedrion files/enall/sin napl.htm [in greek]. 
16. Iwarsson, S., Ståhl, A. 2003. "Accessibility, usability and universal design Positioning and definition of concepts describing person-environment relationships". Disability and Rehabilitation, 25(2): 57-66. Available from: https://www.tandfonline.com/doi/abs/10.1080/dre.25.2.57.66

17. Jansen, D. 2019. Open Education and LLL: role of OER, MOOCs and Short Programs. Open Educational Resources and Lifelong Learning: Opportunities and challenges for Higher Education Institutions and Libraries, 15 March 2019. Book Tower, National Library of Greece, Stavros Niarchos Foundation Cultural Center.

18. Jeffrey, B., Woods, P. 2003. The Creative School. A framework for success, quality and effectiveness. London and New York: Routledge Falmer, Taylor \& Francis Group.

19. Kanellopoulos, A., Koutsoumpa, M. 2017. "Connecting Open and Distance Education. New Technologies and Learning Forms. The case of MOOCs". In Proceedings $-9^{\text {th }}$ International Conference in Open and Distance Learning (ICODL), vol. 4, A', 123-135. Available from: https://eproceedings.epublishing.ekt.gr/index.php/openedu/article/view/1128/13 $\underline{38}$ [in greek].

20. Karampiperis, P., Sampson, D. 2005. Designing Learning Services: From Content based to Activity - based Learning Systems. WWW, May 10-14, Chiba, Japan.

21. Koulikourdi, A. 2009. “Distance Education for All”. Open Education - The Journal for Open and Distance Education and Educational Technology, 5(1).

22. Kouis, D., Christaki, St., Koutsileou, St., Veranis, G. 2019. Senior Software Developer, HEAL-Link / NTUA Branch. The "Kallipos" Project/Repository and the contribution of open academic textbooks in Lifelong Learning. Open Educational Resources and Lifelong Learning: Opportunities and challenges for Higher Education Institutions and Libraries, 15 March 2019. Book Tower, National Library of Greece, Stavros Niarchos Foundation Cultural Center.

23. Krokou, Z. 2007. “Teaching children how to learn". In $1^{\text {st }}$ Educational Conference. Perifereiakh Dieythyhnsh A/thmias kai B/thmias Ekpaideyshs Hpeiroy. Available from: http://epirus.sch.gr/educonf-1html/12.html [in greek].

24. Lambert, S. R. 2020. “Do MOOCs contribute student equity and social inclusion? A systematic review 2014-18". Computers \& Education, 145. Available from: https://www.sciencedirect.com/science/article/pii/S0360131519302465?via\%3Dihu $\underline{\mathrm{b}}$

25. Merakis, L. 2019. Open Courses in Greek Universities: open knowledge available to all. Open Educational Resources and Lifelong Learning: Opportunities and challenges for Higher Education Institutions and Libraries, 15 March 2019. Book Tower, National Library of Greece, Stavros Niarchos Foundation Cultural Center.

26. Mitakidou, S., Tressou, E., Karagianni, P. 2008. “Students' Reflections on Social Exclusion". The International Journal of Diversity in Organizations, Communities, and Nations: Annual Review, 8(5): 191-198. doi:10.18848/1447-9532/CGP/v08i05/39651. 
27. McLoughlin, C., Lee, H.J.W. 2008. Social software and participatory learning: Pedagogical choices with technology affordances in the Web 2.0 era. Available from: https://ascilite.org/conferences/singapore07/procs/mcloughlin.pdf

28. Makri, A. 2018. "E-Learning: Categorization of potentials and challenges in educational environments". In Proceedings $-4^{\text {th }}$ International Conference for the Promotion of Educational Innovation. Larisa, 12-14/10/2018. Available from: http://synedrio.eepek.gr [in greek].

29. Matsangouras, H. 2000. “Collaborative teaching: 'Why', 'How', 'When' and 'for whom'. In Symposioum The application of group collaborative teaching - Trends and applications. Thessalonikh, 8-9/12/2000. [in greek].

30. Meadows, J. 2004. Science and ICT in the Primary School. A Creative Approach to Big Ideas. David Fulton Publishers.

31. Moutean, C. I. 2011. "Raising engagement in e-learning through gamification". In Proceedings of the $6^{\text {th }}$ International Conference on Virtual Learning 2011. Available: http://icvl.eu/2011/disc/icvl/documente/pdf/met/ICVL ModelsAndMethodologie s paper42.pdf

32. Nakaznyi, M., Sorokina, L., Romaniukha, M. 2015. "ICT in Higher Education Teaching: Advantages, Problems, and Motives". International Journal of Research in E-learning, 1(1): 40-61.

33. OECD, "Inclusion of Students with Disabilities in Tertiary Education and Employment DOI" 2011. Retrieved from https://dx.doi.org/10.1787/9789264097650-en

34. Oliver, R. 2003. "The role of ICT in higher education for the 21st century: ICT as a change agent for education". Paper presented at the Higher education for the 21st century conference, Curtin. Retrieved from www.amar.org.ir/Portals/0/Files/abstract/1389/n IT 89.pdf.

35. Papadopoulos, K., Koutsoklenis, A. 2009. "Reading Media Used by HigherEducation Students and Graduates with Visual Impairments in Greece". Journal of Visual Impairment $\mathcal{E}$ Blindness, 103(11): 772-777.

36. Papanikolaou, K. A., Grigoriadou, M., Kornilakis, H., Magoulas, G. D. 2003. "Personalising the Interaction in a Web-based Educational Hypermedia System: the case of INSPIRE". User-Modeling and User-Adapted Interaction, 13(3): 213-267.

37. Pachler, N., Cook, J., Bachmair, B. 2010. "Appropriation of Mobile Cultural Resources for Learning". International Journal of Mobile and Blended Learning (IJMBL), 2(1): 1-21. Doi:10.4018/jmbl.2010010101

38. Pozzi, F. 2011. "The impact of scripted roles on online collaborative learning processes". Computer-Supported Collaborative Learning, 6(3): 471-474.

39. Psacharopoulos, G., Tassoulas, S. 2004. "Achievement at the Higher Education Entry Examinations in Greece: A Procrustean Approach". Higher Education, 47(2): 241-252.

40. Saiti, A., Prokopiadou, G. 2008. "The Demand for Higher Education in Greece". Journal of Further and Higher Education, 32(3): 285-296. doi:10.1080/03098770802221080. 
41. Sianou-Kyrgiou, E., Tsiplakides, I. 2011. "Similar Performance, but Different Choices: Social Class and Higher Education Choice in Greece". Studies in Higher Education, 36(1): 89-102. doi:10.1080/ 03075070903469606.

42. Sogol Talebian, Hamid Movahed Mohammadi, Ahmad Rezvanfar. 2014. "Information and Communication Technology (ICT) in Higher Education: Advantages, Disadvantages, Conveniences and Limitations of Applying Elearning to Agricultural Students in Iran". Procedia - Social and Behavioral Sciences, 152: 300-305. Available from: https://doi.org/10.1016/j.sbspro.2014.09.199 http://www.sciencedirect.com/science/article/pii/S1877042814052665

43. Special Education in Europe. 2003. European Agency for Development in Special Needs Education. Available from: http://www.europeanagency.org/publications/agency publications/SNE europe/SNE.html

44. Tressou, E., Mitakidou, S. Karagianni, P. 2007. "The Diversity in the University: Students' Ideas on Disability Issues". The International Journal of Diversity in Organisations, 7(4): 259-266.

45. UNESCO. 1990. World declaration on education for all and framework for action to meet basic learning needs. Paris: UNESCO.

46. UNESCO. 1994. Salamanca Declaration and Action Plan for Special Education. World Conference on Special Education. Issue of the Greek Commission for UNESCO. Athens.

47. United Nations. 2015. Transforming our world: The 2030 agenda for sustainable development.

Available from: https://www.un.org/ga/search/view doc.asp?symbol=A/RES/70/1\&Lang=E

48. Virnes, M. 2008. Robotics in special needs education. Proceedings of the 7 th international conference on interaction design and children, 29-32. Chicago: ACM.

49. Vlachou, A., Papananou, I. 2018. "Experiences and Perspectives of Greek Higher Education Students with Disabilities". Educational Research, 60(2): 206-221. Available: https://www.tandfonline.com/doi/full/10.1080/00131881.2018.1453752

50. Weller, M. 2014. The battle for open. London: Ubiquity Press. Retrieved from http://www.ubiquitypress.com/site/books/detail/11/battle-for-open/ 
Authors will retain the copyright of their published articles agreeing that a Creative Commons Attribution 4.0 International License (CC BY 4.0) terms wil be applied to their work. Under the terms of this license, no permission is required from the author(s) or publisher for members of the community to copy, distribute, transmit or adapt the article content, providing a proper, prominent and unambiguous attribution to the authors in a manner that makes clear that the materials are being reused under permission of a Creative Commons License. Views, opinions and conclusions expressed in this research article are views, opinions and conclusions of the author(s). Open Access Publishing Group and European Journal of Special Education Research shall not be responsible or answerable for any loss, damage or liability caused in relation to/arising out of conflict of interests, copyright violations and inappropriate or inaccurate use of any kind content related or integrated on the research work. All the published works are meeting the Open Access Publishing requirements and can be freely accessed, shared, modified, distributed and used in educational, commercial and non-commercial purposes under a Creative Commons Attribution 4.0 International License (CC BY 4.0). 